\title{
Optimum white clover content for dairy pastures
}

\author{
S.L. HARRIS, D.A. CLARK, M.J. AULDIST, C.D. WAUGH and P.G. LABOYRIE \\ Dairying Research Corporation, Private Bag 3123, Hamilton
}

\begin{abstract}
In February 1996, 48 Friesian and Jersey cows grazed pastures containing nominally $0,25,50$ or $75 \%$ of dry matter (DM) as white clover with the balance mainly $\mathrm{C} 4$ grasses at either ad lib. $(50 \mathrm{~kg}$ $\mathrm{DM} /$ cow/day) or restricted (25 kg DM/cow/day) allowances. The aim of the trial was to measure the effect of clover content on milk yield and composition, and to determine the optimum clover content for milk production. Milk yields of cows on the ad lib. allowance grazing $25 \%$ clover were $22 \%$ higher $(\mathrm{P}<0.05)$ than yields of cows grazing $0 \%$ clover. Milk yields on 50 and $75 \%$ clover were similar, 33\% higher $(\mathrm{P}<0.05)$ than for cows grazing $0 \%$ clover. The differences were similar for cows on the restricted allowance. Clover content had little effect on milk composition except for a decrease in fat \% with increasing clover content. The trial showed increased milk yields were owing to both increased intakes associated with high clover diets, and the higher nutritive value of the clover. Results showed that a clover content of $50 \%$ is a realistic target to increase milk yields considerably. Increasing clover content above $65 \%$ would do little to increase milk production further.
\end{abstract}

Keywords: Friesian cow, herbage intake, Jersey cow, milk composition, milk yield, nutritive value, perennial ryegrass, smooth witchgrass, summer grass, white clover

\section{Introduction}

British (Thomson 1984), Australian (Rogers et al. 1979, 1980, 1982; Rogers \& Robinson 1984) and New Zealand (Johnson \& Thomson 1996) research has clearly shown the benefit of pure white clover over pure perennial ryegrass for increased milk production, particularly in the second half of lactation. However, pure clover pastures are unrealistic for New Zealand dairy farms owing to their lower annual DM production, the higher bloat risk and difficulties in maintaining such swards. Mixed perennial ryegrass-white clover pastures therefore remain a better option than pure swards, but the clover content would need to be higher than the current average of $10-20 \%$ to increase milk production. This paper reports on the first in a series of grazing experiments at the Dairying Research Corporation (DRC) investigating the effect of clover content on milk production, with the aim of determining an optimum clover content for New Zealand dairy pastures. The overall goal of the research is to increase summer-autumn milk production.

\section{Materials and methods}

The February 1996 trial measured herbage intake, milk yield and milk composition of cows grazing swards containing nominally $0,25,50$ or $75 \%$ (\% of total DM) white clover. Low endophyte perennial ryegrass (Lolium perenne $\mathrm{cv}$. Yatsyn 1) - white clover (Trifolium repens cv. Grasslands Kopu) pastures were sown in spring 1995 using different seed rate combinations. Pastures were spray/drilled following the winter in annual ryegrass. Herbage production and clover content were regulated to required targets using irrigation, grazing, spraying herbicides to suppress ryegrass growth or eliminate clover, and $\mathrm{N}$ fertiliser applications. The chemical composition of the herbage was analysed using near-infrared spectroscopy (NIRS) (Ulyatt et al. 1995) to provide an indication of feed quality.

Twenty-four Friesian and 24 Jersey cows were allocated to treatment groups balanced for breed, age, current milk yield and milk composition. Cows were fed at two different allowances, ad lib. (50 kg DM/ cow/day) or restricted $(25 \mathrm{~kg} \mathrm{DM} /$ cow/day), which allowed the relative contributions of increased intake and improved feed quality on milk yield at different clover contents to be determined. Cows remained on the same allowance for two 10-day periods but changed to a different clover content for the second period, i.e., one Jersey and one Friesian cow from each treatment to each of the alternative clover levels. All cows received bloat drench $(50 \mathrm{ml}$ 1:6 Bloatenz 2in1 (Ecolab Ltd, New Zealand)) at every milking.

Milk yield and composition (fat, protein and lactose) were measured daily ( $\mathrm{pm}+$ am milking) over the final 5 days of each period. Herbage intake was estimated over the same 5 days using the alkane technique (Dove \& Mayes 1991). Capsules containing synthetic C32 and $\mathrm{C} 36$ alkanes were administered to cows twice daily 
starting 2 days before the trial. Individual faecal samples, collected twice daily, were bulked, analysed for alkane content, together with herbage samples representative of what cows were grazing, and intake calculated for each cow.

A cross-over model in SAS was used to analyse the data. Milk yield and composition data collected over the three weeks before the trial, when cows were grazing the same "typical" pasture, were used as a covariate in the model. Linear and quadratic regression analyses of milk and milksolids (MS) yield were used to identify the optimum clover content.

\section{Results}

Botanical composition measurements showed the sown pastures were close to the desired clover contents, although the companion species were mainly summer grass (Digitaria sanguinalis) and smooth witchgrass (Panicum dichotomiflorum), with little ryegrass (Table 1). Susceptibility to insect attack probably contributed to the lack of persistence of the low endophyte ryegrass.

The feed quality of the pasture was improved with increasing clover content owing to higher crude protein, in vitro digestibility and metabolisable energy (ME) levels, and lower fibre contents (Table 2).

Increasing clover content in the pasture was associated with increased milk yield for cows fed both the $a d l i b$. and restricted allowances. Ad lib. fed cows grazing $25 \%$ clover produced $22 \%$ more milk $(\mathrm{P}<0.05)$ than those grazing $0 \%$ clover (Table 3 ). Cows grazing $50 \%$ and $75 \%$ clover had similar milk yields, $33 \%$ greater $(\mathrm{P}<0.05)$ than the $0 \%$ clover herd.

Milk yield response to clover content was similar for cows on the restricted diets, although overall milk yields were lower than for the fully fed cows (Table 4). Cows grazing $25 \%$ clover produced $23 \%$ more milk $(\mathrm{P}<0.05)$ than those grazing $0 \%$ clover. Again there was no significant difference in milk yields between cows grazing $50 \%$ and $75 \%$ clover with average milk yields $35 \%$ greater $(\mathrm{P}<0.05)$ than yields of cows grazing $0 \%$ clover.

Herbage intake, like milk yield, increased in response to increasing clover content for cows offered an ad lib. diet (Table 3). Daily intakes of cows grazing 25\%, 50\% and $75 \%$ clover were $8 \%(\mathrm{P}<0.10), 23 \%(\mathrm{P}<0.05)$ and $30 \%(\mathrm{P}<0.05)$ greater, respectively, than intakes of cows grazing $0 \%$ clover. As expected, intakes of cows on restricted allowances were not significantly different under the different clover levels (Table 4).
Table 2 Pasture dry matter (\%), crude protein, neutral detergent fibre and in vitro digestibility $(\mathrm{g} / 100 \mathrm{~g}$ DM), and estimated metabolisable energy (ME) (MJ/ $\mathrm{kg}$ DM).

\begin{tabular}{lllll}
\hline Nominal clover content & $0 \%$ & $25 \%$ & $50 \%$ & $75 \%$ \\
\hline Dry matter & 21.0 & 16.4 & 14.9 & 15.0 \\
Crude protein & 14.3 & 16.4 & 18.4 & 21.9 \\
Neutral detergent fibre & 61.8 & 52.6 & 47.7 & 40.4 \\
In vitro digestibility & 64.1 & 68.0 & 70.7 & 71.8 \\
Estimated ME & 9.5 & 10.1 & 10.5 & 10.7 \\
\hline
\end{tabular}

Table 3 Effect of clover content (\% total DM) on herbage intake (kg DM/cow/day), milk yield (I/cow/day), milk composition (fat \%, protein \%, lactose \%) and milksolids yield (kg MS/cow/day) of cows offered an ad lib. (50 kg DM/cow/day) allowance.

\begin{tabular}{lrrrrr}
\hline Clover content & \multicolumn{1}{c}{$0 \%$} & \multicolumn{1}{c}{$25 \%$} & $50 \%$ & $75 \%$ & SED \\
\hline Intake & 12.10 & 13.07 & 14.84 & 15.78 & 0.72 \\
Milk yield & 10.24 & 12.54 & 13.57 & 13.72 & 0.34 \\
Fat \% & 5.80 & 5.56 & 5.35 & 5.48 & 0.18 \\
Protein \% & 3.80 & 3.79 & 3.77 & 3.86 & 0.05 \\
Lactose \% & 4.88 & 4.95 & 4.97 & 5.00 & 0.02 \\
Milksolids & 0.96 & 1.17 & 1.24 & 1.26 & 0.03 \\
\hline
\end{tabular}

Table 4 Effect of clover content (\% total DM) on herbage intake (kg DM/cow/day), milk yield (I/cow/day), milk composition (fat $\%$, protein $\%$, lactose $\%$ ) and milksolids yield ( $\mathrm{kg} \mathrm{MS} / \mathrm{cow} /$ day) of cows offered restricted (25 kg DM/cow/day) allowance.

\begin{tabular}{lrrrrr}
\hline Clover content & \multicolumn{1}{c}{$0 \%$} & $25 \%$ & $50 \%$ & $75 \%$ & SED \\
\hline Intake & 10.89 & 11.10 & 11.47 & 11.59 & 0.91 \\
Milk yield & 9.03 & 11.08 & 11.91 & 12.44 & 0.35 \\
Fat \% & 5.73 & 5.48 & 5.42 & 5.09 & 0.18 \\
Protein \% & 3.79 & 3.75 & 3.79 & 3.74 & 0.05 \\
Lactose \% & 4.85 & 4.89 & 4.89 & 4.98 & 0.04 \\
Milksolids & 0.84 & 1.01 & 1.09 & 1.10 & 0.03 \\
\hline
\end{tabular}


Clover content had little effect on milk composition (fat, protein and lactose \%) for both ad lib. (Table 3) and restricted allowance (Table 4) cows. Fat \% generally decreased with increasing clover content but there was no effect on protein\%. Fat and protein yields, however, both increased with increasing clover content owing to the effect of higher milk yields. As a result MS yields showed a similar trend to milk yields; increasing with higher clover contents but with no significant difference in MS yields between cows grazing 50\% and 75\% clover (Tables 3 and 4).

\section{Discussion}

A number of studies (Rogers et al. 1979, 1980, 1982; Rogers \& Robinson 1984; Thomson 1984) have shown milk production of cows fed white clover was higher than for cows fed pure perennial ryegrass. Our trial also showed milk yields were higher with increased white clover contents in pasture. However, the dominant grass species was not perennial ryegrass, as was intended, but instead a mixture of $\mathrm{C} 4$ species (summer grass and smooth witchgrass) and a small amount of ryegrass. Relative to perennial ryegrass, summer grass and, in particular, smooth witchgrass have lower levels of crude protein and soluble sugars, and increased NDF contents (Jackson et al. 1996). The presence of these C4 grasses would therefore be expected to reduce the nutritive value of pasture and, combined with a probable decrease in voluntary herbage intake (Minson 1981), would likely decrease milk production. In our trial the high levels of $\mathrm{C} 4$ grasses, instead of ryegrass, may have exaggerated the effect of clover content on milk production, although the yields of cows grazing $0 \%$ clover were not unduly low given the stage of lactation. In addition the trial showed a similar trend in milk production to an indoor trial at DRC where cows were fed diets containing either 20,50 or $80 \%$ white clover with the balance perennial ryegrass (Harris et al. 1997).

The increased milk yield in response to higher white clover levels in the diet was due to both feed quality and quantity factors. White clover has a higher nutritive value than grasses, owing to lower levels of structural carbohydrate, higher digestible protein and a faster rate of passage through the rumen (Ulyatt 1981). In addition, bacterial populations in the rumen of cows fed pure clover were higher than for cows fed pure ryegrass and use of proteins and amino acids more efficient (Thomson 1984). Consequently, increasing clover level in the diet improved digestibility and increased protein and metabolisable energy intakes (Table 3 ), and so contributed to the measured increase in milk production. There is, however, an energy cost for the cow associated with metabolising high protein (high clover) feeds which may reduce potential milk production (Danfaer et al. 1980). Although none of the clover diets fed in this trial had particularly high crude protein levels, a protein penalty effect at high clover contents may explain why milk yield response to increasing clover content was non-linear.

Australian studies showed intakes of cows grazing pure clover were $15-33 \%$ higher than for those grazing pure ryegrass (Rogers et al. 1979, 1980). Our results support these findings since ad lib. fed cows grazing 75\% clover consumed $30 \%$ more than those grazing $0 \%$ clover. Although the digestibility of the diets used here increased with increasing clover content, other studies have shown ruminants consume more white clover than perennial ryegrass at the same digestibility (Thomson 1984). The higher nutritive value of clover was equally as important as intake in contributing to the increased milk production in the DRC trial, since differences in milk yields of cows offered a restricted diet were similar to those fed ad lib. despite the restricted cows having similar intakes on all clover levels. Australian studies showed similar results (Rogers et al. 1979; 1980, Santamaria \& Rogers 1980).

Increasing clover content had little effect on milk composition. The only effect was decreased milk fat $\%$, but other clover feeding trials at DRC (Harris et al. 1997; Harris unpubl.) have shown no effect of increased clover content on milk composition. Since these other DRC studies used perennial ryegrass, the effect on fat $\%$ seen here may have been owing to the $\mathrm{C} 4$ grasses rather than a clover content effect. Other studies comparing clover and ryegrass have, however, shown a range of effects on milk composition including decreased fat $\%$ and increased protein $\%$ (Rogers et al. 1980; Thomson et al. 1985), lower fat \% but no effect on protein \% (Santamaria \& Rogers 1980), or no effect of clover on milk composition (Rogers et al. 1979; Rogers \& Robinson 1984). Similar inconsistencies have been reported for another New Zealand study comparing pure clover and ryegrass diets (Johnson \& Thomson 1996).

The results of this experiment indicated an asymptotic response of milk yield to clover content such that cows grazing $75 \%$ clover had similar yields to cows grazing 50\% clover. Plotting milk yield against clover content (where $\mathrm{x}$ is the proportion of white clover in the diet ranging from $0-1$ ) gave the following asymptotic curve:

milk yield $=14.124($ S.E. $=0.819)-4.029($ S.E. $=$ $0.852) * 0.0301^{\mathrm{x}}($ S.E. $=0.0586)$

$$
\mathrm{R}^{2}=0.482, \mathrm{RSD}=1.43 \quad \text { (Figure 1) }
$$


Figure 1 Milk yields of cows grazing different clover contents on an ad lib. allowance ( $50 \mathrm{~kg} \mathrm{DM} /$ cow/day).

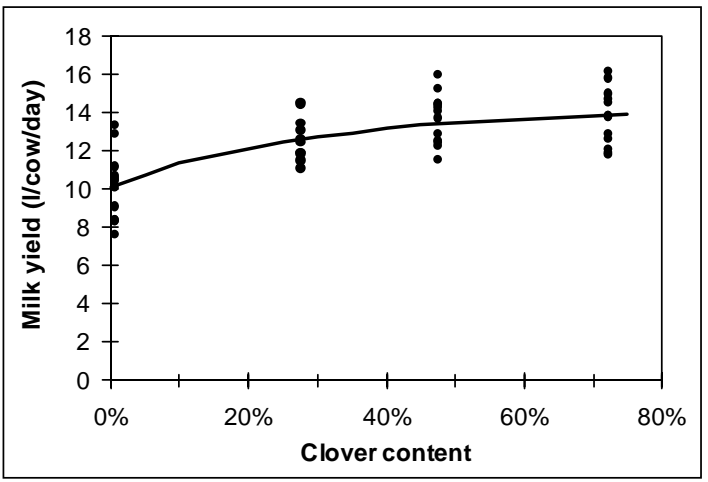

Thus this trial indicated cows fed $65 \%$ clover diets would have yielded $98 \%$ (13.8 1/cow/day) of the milk produced by cows fed $100 \%$ ( $14.1 \mathrm{l} / \mathrm{cow} /$ day $)$ clover diets. Given that achieving such high white clover contents in a grazed pasture situation may prove difficult, a clover content of $50 \%$ may be a more realistic option since cows grazing such a pasture could be expected to produce $95 \%$ (13.4 1/cow/day) of maximum possible milk yield.

The ability of white clover to maintain a higher nutritive value than grass species through summer (Thomson 1984) means that most benefit from increasing clover content is likely after peak lactation. The comparatively high nutritive value of ryegrass during spring, associated with a high growth rate, means benefits from increased clover content during spring would be small. This trend was shown in an Australian study comparing milk production of cows on pure ryegrass and pure clover swards throughout lactation (Rogers \& Robinson 1984). If increasing clover content in dairy pastures to increase milk yields is a viable option for New Zealand dairy farmers, the mid to late stages of lactation appear to be the period to target. Fortunately this coincides with summer-autumn, when clover contents in dairy pastures are highest (Harris 1994).

\section{Conclusion}

Increased pasture clover content resulted in higher milk yields owing to a combination of higher herbage intakes and increased nutritive value of the pasture. The effects on milk composition, however, were small. Current clover contents in dairy pastures (10-20\%) are considerably lower than the levels needed for near maximum milk production (50-65\%). Further outdoor grazing trials are necessary, however, before an optimum clover content for New Zealand dairy pastures can be determined, since the effect of clover content on total herbage production, as well as on milk production, must be taken into account. The goal should be to increase the clover content of dairy pastures, without compromising annual pasture yield, in order to increase milk production.

\section{ACKNOWLEDGEMENTS}

The authors thank Roslyn McCabe, Vicki van Vught and farm staff at No 5 Dairy for technical help, Ross McKee and Paul Sutherland for alkane analysis, and Rhonda Hooper for statistical assistance.

\section{REFERENCES}

Danfaer, A.; Thysen, I.; Ostergaard, V. 1980. The effect of dietary protein on milk production. Research report No. 492, Copenhagen; Bereting fra Statens Husdyrbrygs Forsog.

Dove, H.; Mayes, R.W. 1991. The use of plant wax alkanes as marker substances in studies of the nutrition of herbivores: a review. Australian journal of agricultural research 42: 913-952.

Harris, S.L. 1994. White clover growth and morphology in dairy pasture in the Waikato region of northern New Zealand. New Zealand journal of agricultural research 37: 487-494.

Harris, S.L.; Clark, D.A.; Jansen, E.B.L. 1997. Optimum white clover content for milk yield. Proceedings of the New Zealand Society of Animal Production 57: 169-171.

Jackson, F.S.; McNabb, W.C.; Peters, J.S.; Barry, T.N.; Campbell, B.D.; Ulyatt, M.J. 1996. Nutritive value of subtropical grasses invading North Island pastures. Proceedings of the New Zealand Grassland Association 57: 203-206.

Johnson, R.J.; Thomson, N.A. 1996. Effect of pasture species on milk yield and milk composition. Proceedings of the New Zealand Grassland Association 57: 151-156.

Minson, D.J. 1981. Nutritional differences between tropical temperate pasture. pp. 143-157. In World Animal Science. B1. F.H.W. Morely (Ed.). Elsevier.

Rogers, G.; Porter, R.; Robinson, I. 1979. The utilization of perennial ryegrass and white clover by lactating dairy cows. Dairy Production Research Report. Department of Agriculture and Rural Affairs, Australia, pp. 59-60.

Rogers, G.L.; Porter, R.H.D.; Robinson, I. 1982. Comparison of perennial ryegrass and white clover for milk production. In Dairy Production from Pasture. Proceedings of New Zealand and 
Australian Societies of Animal Production, pp. 213214.

Rogers, G.; Robinson, I. 1984. Whole lactation production of cows grazing white clover or perennial ryegrass. Dairy Production Research Report. Department of Agriculture and Rural Affairs, Australia, pp. 148-149.

Rogers, G.; Robinson, I.; Porter, R. 1980. The utilization of perennial ryegrass and white clover by lactating dairy cows. Dairy Production Research Report. Department of Agriculture and Rural Affairs, Australia, pp. 54-55.

Santamaria, A.; Rogers, G. 1980. Comparative effects of white clover and perennial ryegrass on milk yield and composition of the grazing cow. Dairy Production Research Report. Department of
Agriculture and Rural Affairs, Australia, pp. 5657.

Thomson, D.J. 1984. The nutritive value of white clover. Occasional symposium of the British Grassland Society 16: 78-92.

Thomson, D.J.; Beever, D.E.; Haines, M.J.; Cammell, S.B.; Evans, R.T.; Dhanoa, M.S.; Austin, A.R. 1985. Yield and composition of milk from Friesian cows grazing either perennial ryegrass or white clover in early lactation. Journal of dairy research 52: 17-31.

Ulyatt, M.J. 1981. The feeding value of herbage: can it be improved. New Zealand journal of agricultural research 15: 200-205.

Ulyatt, M.J.; Lee, J.; Corson, D. 1995. Assessing feed quality. Proceedings of the Ruakura Farmers' Conference 47: 63-70. 
